\title{
Birmingham Rep, youth and community, and the products and possibilities of precarity
}

\section{Claire Cochrane}

AQ1 Institute of Humanities and Creative Arts, University of Worcester, Worcester, UK

\section{ABSTRACT}

Birmingham Rep, a leading producing theatre based in the UK's 'second city', has historically had a complex relationship with the cultural priorities of its home city. In recent years, Birmingham City Council has faced multiple challenges represented by debt burden, government-imposed cuts in public funding, scandals linked to failing children's services and fears of Islamic radicalisation in the city's schools. From a detailed consideration of the way the Rep's artistic policy has been shaped in the context of chronic financial instability and these broader challenges, I argue that the increasingly central position youth and community engagement has assumed signals a major paradigm shift in the expectations associated with the role and function of the regional producing theatre in the UK.

\section{ARTICLE HISTORY}

Received 29 February 2016 Accepted 18 November 2016

\section{KEYWORDS}

Birmingham; community; resilience; producing; city; young people

This article considers the centrality of engagement with children and young people, their families and the wider community, to the work and policy decisions of the Birmingham Repertory Theatre. This core commitment not only represents a major departure from the original founding principles of this major British regional producing theatre based in the UK's 'second city', but also necessitates, I argue, a more fundamental reappraisal of the criteria by which a theatre institution is evaluated as a creative agent. As I delineate below, this position has been reached gradually over a period of time dating back as far as the late 1960s and it has been inextricably linked to the exigencies of shifting financial support structures and policies. In general theatre makers, including those operating with public subsidy, rarely work within stable material circumstances. The economic model known as the 'third sector', where artists and their enablers have to manoeuvre between the multiple challenges of not-for-profit aesthetic and social idealism and commercial business interests (Anheier 2005,4) means that precariousness is a permanent state. Without doubt the initial turn towards a policy of greater engagement with children and young people was driven by managerial pragmatism, although this is not to suggest that early activity was conducted cynically. But the move from relative marginality to absolute centrality in the theatre's work, unequivocally demonstrates the recognition that fuller representation of the interests of young people and their families is vital both to a richer and more inclusive experience of theatre and to the cultural life of the city as a whole. 
As the theatre's most recent historian, I have charted Birmingham Rep's artistic journey, which began over a hundred years ago in the city where I was born and educated. My earliest memory of theatre-going arises from being taken to see a Christmas play at the Old Rep as a young child, and as a regular audience member since then I can claim to have lived through the consequences of many of the policy changes I have analysed as a researcher. ${ }^{1}$ Viewing the theatre through the lens of urban theory, I have become more and more preoccupied with the way regional, building-based producing theatres negotiate their role and representative artistic function within the cities that support them.

AQ2 Writing about the early history of the Birmingham Repertory Theatre (Cochrane 2000,

144), I argued that there was a radical disjunction, ideologically and aesthetically, between the spaces inside and outside the theatre building which successive directorates have attempted, with varying degrees of success, to overcome.

I begin with a moment in the 2015-2016 artistic programme of the theatre, highlighting what it meant for those, including myself, intimately involved in this event, and also exploring its significance for understanding the theatre's relationship to the city. I then provide an historical overview of the key phases in the REP's record while also setting out the wider economic, political and social factors which have combined to create an exceptionally difficult set of circumstances that have shaped the ways the theatre has reached out to young people and their parent communities in recent years.

\section{Abuelo}

14 January 2016. I'm at the Birmingham Repertory Theatre sitting in the Door, the small black box space dedicated to new writing, and I'm watching a solo performance by Amahra Spence, a former student of Worcester University where I teach. Switching between two distinctive voices, one her native 'Brummie', the other Jamaican, her play Abuelo braids together her life as a 23-year-old Birmingham-born, pregnant young woman with the recollections of her garrulous allotment-obsessed, gambling grandfather. His stories of his journey from the Caribbean to England at the age of 16 are helping her make sense of her heritage, identity and the life changes she faces. I'm also thinking about Amahra's more recent journey, which began in my office four years ago. Anxious about money, she had to be persuaded to take up an opportunity offered by a work placement module which saw her in the REP's centenary year sitting in caravan recording the memories of local people as part of the theatre's Heritage Lottery Fund project. I'm thinking about her first encounter with Roxana Silbert, the REP's new Artistic Director who came to talk to students about her production of Dennis Kelly's Orphans, which premiered in the Door in 2009. As a writer-actor, Amahra is a product of the REP Foundry - a scheme designed to nurture the aspirations of new - mostly young, but some simply new-local theatre makers.

The night of Abuelo's premiere, the Door looked nearly full. In the audience were relatives, friends, Roxana Silbert and Daniel Bailey, the young black assistant resident director who directed Amahra's work. The rest of the audience - roughly 130 in a space which seats 140, represented a microcosm of Birmingham's multiple-heritage population, visibly embodying the city's diverse and complex demographic. Outside the theatre, there were other more ominous signifiers of urban complexity and its 
challenges. The lights in the long foyer area, which physically connects the REP to the new Library of Birmingham, were dim. The large, glass-fronted revolving door intended to admit both audience and library users was locked. The Library's formerly generous opening hours had been cut and there had been significant staff redundancies. In January 2016, then, the REP had no main front door for evening theatre attendees, who instead had to use a comparatively obscure, glass disabled-access door opposite the box office. The $£ 189$ million Library, the largest regional library in Europe, was opened in September 2013 by Malala Yousafzai, the 16-year-old Pakistani girl shot by the Taliban, whose life and intellectual capacity were saved by Birmingham doctors and who later became a pupil at a prestigious girls' school in the city. The joining of the refurbished theatre, the home of the longest continuously trading building-based theatre company in the UK, to the Library was a powerful and optimistic statement of Birmingham's cultural priorities. But this story of optimism stifled by a UK government policy of austerity also shows how firmly theatre is tied to the constantly fluctuating fortunes of the city.

Back in 1991, an earlier example of the kind of high-profile and expensive projects, which urban geographer Phil Hubbard has described as 'civic boosterism' (Hubbard 2006 , 86-87), saw the building of the $£ 200$ million International Convention Centre literally a few feet away from the Rep. Fronting the newly created Centenary Square, this massively impressive marble and steel meeting place houses Symphony Hall, arguably the UK's best concert hall, making the theatre much more visibly prominent. The immediate consequences for the Rep's management, however, was a crippling debt burden arising from loans made for an associated extension and refurbishment costs. As I have recounted elsewhere (2003) the two most significant victims of this were the Rep's artistic directors John

115 Adams and his successor Bill Alexander, both of whom were forced to resign because of financial failure directly associated with this toxic legacy. In the case of Alexander, this was exacerbated by the disastrous outcomes of the Arts Council's $£ 5,773,000$ 'stabilisation' AQ3 award (Cochrane 2001, 203-205).

- By 2016, Birmingham City Council, the largest local authority in the UK, was trapped within what the leader of the Labour-controlled council, Sir Albert Bore, had previously represented as the 'jaws of doom'. In 2013, Bore presented to the Birmingham public a graph showing rising budgetary pressures and rapidly dwindling central government grants (depicting a grant reduction of $£ 332$ million by 2016-2017), with the lines on the graph creating a visual image which could have been a child's drawing of a shark about to swallow its prey. Cuts to spending on local services were predicted to amount to an estimated $£ 273$ million, which meant $£ 600$ million of savings: nearly half of the council's controllable spending (Butler 2012). Two years later, the shark ate Albert Bore - he was compelled to resign in October 2015 after his own Labour cabinet members lost confidence in his leadership (Brown 2015). Shortly after that, the REP was informed of a $29 \%$ reduction in the annual grant it receives from the council. As a joint response, published just a month before the staging of Abuelo, from the Artistic Director Roxana Silbert and Executive Director Stuart Rogers stated, at the time of this cut, the theatre had already absorbed a $34 \%$ reduction via a cut in its Arts Council England subsidy which, together with the council cut, added up to a total cut of 52\% since 2010 (Silbert and Rogers 2015). 


\section{A city's theatre}

Birmingham Rep has had a particularly complicated relationship with its city and indeed with money. Considered alongside other theatres associated with the origins of the early twentieth century repertory movement in the UK, Birmingham Rep stands out because of the financial cushion provided by its wealthy founder Sir Barry Jackson whose rhetoric, if not always his actual entrepreneurial practice, positioned the company in implacable opposition to any attempt to prioritise commercial purpose over artistic vision. In 1935, the creation of the Sir Barry Jackson Trust effectively gave the theatre to the city, although Jackson remained in overall artistic control until his death in 1961. A refusal to commodify the artistic product was accompanied by a wariness of the potential threat to independence which public funding might bring - a not unusual response amongst arts institutions in the early years of subsidy. Birmingham City Council awarded the theatre its first grant of $£ 3000$ in 1951 and in 1955 the then Arts Council of Great Britain (ACGB) regarded its first grant to the theatre of $£ 500$ as a cause of celebration. But the core founding vision, predicated on the early twentieth century radical modernist mission to produce plays of intellectual or aesthetic 'quality', directed and performed as expertly as possible to receptive, discerning audiences, remained intact.

Unlike the Belgrade Theatre in Coventry, located geographically very close to Birmingham and which had pioneered the first theatre-in-education company in 1965, the Rep did not establish a coherent record of youth and community engagement at the outset. In the 1960s, within the limitations of the original 1913 building, there had been attempts to attract young audiences with specially tailored lectures and Saturday morning workshops. Theatre '67, a club for young people established in 1967 with the assistance of an ACGB grant, eventually attracted an impressive membership of nearly 1000 . During the 1970s, after the move to the present much larger building with its then two auditoria, there were sporadic attempts at community touring and children's theatre. The Birmingham Youth Theatre, led by English teachers Derek Nicholls and Ray Speakman, encouraged the talents of young black actors such as Adrian Lester, Joe Dixon and Lorna Laidlaw and maintained an intermittent performance home for young people's performance in the Studio. By 1984, however, the theatre had survived two potentially fatal deficit crises. The first in 1973 when the management struggled with the demands of a large plant at a time of global economic turmoil and rapid prices rises, and the second in 1983 when a huge deficit exposed inadequate financial controls. On both occasions the two major funders, the Arts Council and Birmingham City Council, came to the rescue. In 1983 this went as far as installing, amidst huge controversy, the former Labour Leader of the Council as Commercial and Financial Director to work alongside the Artistic Director Clive Perry. It is at this point that the influence of global forces intervened in what now, with hindsight, I want to argue was a transitional moment of some significance.

\section{An emphatic turn}

As is well recognised, in the case of regional British building-based producing theatres which were largely - albeit with exceptions such as the Rep - the product of post-1945 State and civic subsidy, the rise of a free-market-led, 'monetarist' ideology in the 1980s resulted in funding pressures on theatres which compelled much closer attention to 
more flexible sources of finance and to becoming far less dependent on the public purse. I have argued elsewhere, however, that even when the public subsidy ethos was stronger in the 1960s and 1970s, theatre managements had to adopt pragmatic strategies for survival AQ4 which necessitated both artistic compromise and/or profit-led facilitators $(2001,172)$. The

1 auguries of the radical changes to come were already apparent in the 1970s, especially after the economic effects of the 1973 oil crisis. The Association of Business Sponsorship (ABSA) for example, designed to encourage a stronger relationship between business and the arts, was founded in 1976 under a Labour government (Dorney and Merkin 2010, 6) and before the term monetarism and its underpinning neoliberal precepts achieved widespread currency.

In tracing the global emergence of economic neoliberalism, the geographer David Harvey describes how 'embedded liberalism' developed after the economic crises of the 1930s when market processes were 'surrounded by a web of social and political constraints' (Harvey 2007, 11). As Harvey acknowledges, and the economist Oliver Marc Hartwich states more explicitly, what has come to be seen 'as an inhuman, anti-social and potentially misanthropic ideology' (Hartwich 2009, 4), has its roots in support for political ideals of human dignity and individual freedom in the face of the evils of economic depression and the fascist and communist dictatorships of the 1930s. Hartwich, tracing the coinage of the term to the work of the German sociologist and economist Alexander Rüstow in 1938, insists that 'one of the defining features of early neoliberal conceptions was to put a check on unfettered markets and market power' $(2009,6)$.

Harvey pinpoints a particular convergence of political and economic events between 1978 and 1980 which provoked, in reaction to inflationary stagnation, an 'emphatic turn' to the doctrine of the unfettered market represented by Margaret Thatcher and 205 her US counterpart Ronald Reagan (Harvey 2007, 1-2). The sense that public funding cuts were an ever-present possibility began within months of Margaret Thatcher's election victory in 1979 and hit home hardest in the theatre with the notorious 'Christmas cuts' of 1980 and this led to the development of more overt and systematic approaches to theatre as a commodity. As Kate Dorney and Ros Merkin have pointed out, in this period the language of theatre management changed to embrace terms which have now become familiar, such as 'marketing, efficiency, cost-effectiveness, business incentives, performance indicators, challenge funding, sponsorship, private sector partnerships, enhancement funding' $(2010,5)$. Simultaneously, however, even as the measurement of success or failure appeared predicated on the priorities of the market place, another equally powerful pressure, emanating from a challenge to the priorities of public funding and then assimilated into Arts Council policy, was for building-based theatres to engage more substantially with their local communities. This can be seen quite clearly in the ACGB's report The Glory of the Garden produced in 1984, the published output of an enquiry chaired by the monetarist-adherent Sir William Rees-Mogg, who had been tasked with considering ways in which the UK arts 'garden' could bloom more equitably outside London. The commitment of an additional $£ 2$ million for regional drama provision was targeted mainly at the expansion of existing building-based repertory companies' responsibility (my emphasis) for two broad objectives. These were: 'to sustain the highest artistic standards of theatrical performance and to bear a much greater responsibility than they have in the recent past for enriching the theatrical experience of the wider community in the whole of their regions'. 'In return' for this largesse ACGB expected companies to: 
play a full part in arranging activities extending beyond the staging of productions in their own main houses. Such activities might include, for example, expanded seasons of studio work (with particular emphasis on new writing), providing facilities for both small-and larger-scale incoming touring companies, touring some of their own main-house and studio work ... providing a focus for the provision of Theatre-in-Education and Young People's Theatre. Repertory companies will also be encouraged, where appropriate, to house independent small-scale companies in their studios and to provide them with access to their own much more extensive administrative, technical and marketing resources. (Arts Council of Great Britain 1984, 16)

l'd like to pause for a moment to consider some of the origins of an apparently binary mentalite about neoliberal arts policy, and to counter this with the suggestion that what this historical moment highlights is that a monetarist model exhibiting the democratising impulses associated with the early forms of neoliberalism (identified by Hartwich) and the imperative to engage more diverse publics, are interrelated rather than opposed. The sheer variety of 'alternative' theatre makers encountering audiences located outside conventional theatre buildings listed in The Glory of the Garden injunction is indicative of a movement which proliferated in the 1970s and has been very well documented, most recently and succinctly by Chris Megson (Megson 2012, 37-58). The responsibilities emphasised by The Glory policy statement arguably attempt to transfer a high proportion of the concomitant alternative funding pressures to the building-based companies thereby justifying the support given to the theatres created as outcomes of $1960 \mathrm{~s}$ AQ5 'Housing the Arts' era which prioritised new building projects $(2001,184-185)$. The preoc-

1 cupation with bringing theatre to the people extends at least as far as radicals such as George Bernard Shaw in the 1890s. But the 1970s generation of community theatre makers came into being at much the same time as a broader philosophical debate about the very nature of democracy and the relationship of the individual to the collective was gathering momentum.

The discourse of communitarianism developed in the 1970s as a reaction to the liberal individualism, is perhaps best summarised by the American philosopher John Rawls in his landmark 1971 book $A$ Theory of Justice. Rawls' theory is that human beings can decide on fair forms of distributive justice from an imagined 'original position' and from 'behind a veil of ignorance' (1999, 118-123). That is, as free individuals unencumbered by any of the assumptions and preconditions imposed by knowledge of their actual status in society. This argument was perceived by Rawls' critics as an asocial rejection of the fundamental values of human association and reciprocal relations as the basis of self-identity. The debate between 'individualists' and various leading 'communitarians', including the philosopher Alasdair Maclntyre and sociologist Amitai Etzioni, contributed to a growing polarisation of positions on the most desirable way to achieve the just society (Little 2002, 2954). The ACGB injunction in 1984 to regional repertory theatres to achieve the twin objectives of creating art of the highest possible standard, while simultaneously coming up with community enrichment strategies, effectively encapsulates the interrelating tensions between individualism and communitarianism in this historical moment. Neither philosophy appeared equal to the challenge presented by macroeconomic circumstances: the collapse of the Keynesian social democratic consensus and the challenge to the principles of welfare capitalism, that is, embedded liberalism, which had offered security to the post1945 generation. 


\section{Glory and its aftermath}

The aftermath of The Glory of the Garden, including subsequent major reports, have been much revisited and critiqued not least in the 2010 collection of essays co-edited by Kate Dorney and Merkin which surveys the impact of Arts Council policy on English regional theatre between 1984 and 2009 (2010). My research into the history of one of the largest regional producing theatres in the UK suggests that Glory's categorical statement of theatres' responsibilities marks a particular moment of clearly articulated change: a moment when the economic means of survival become tied to a State-imposed imperative of some consequence. Furthermore, there is growing evidence of a major paradigm shift in what and whom ideologically, aesthetically and socially, the resources of a regional building-based producing theatre company are expected to achieve and serve.

Returning specifically to the aftermath of Glory in Birmingham, it is important to stress the contribution that both the immediate post-Glory artistic directors John Adams (19871992) and Bill Alexander (1993-2000) brought to the juggling act imposed by these dual economic and social responsibilities. Both men enhanced the producing dynamism of the theatre conceptually, politically and scenographically, working to fulfil the first responsibility to create the highest possible standards of artistic performance. Bill Alexander in particular insisted that a regional theatre was not to be treated primarily as a training ground for artists who would 'move on' to achieve maturity in the metropolis. Under him and associates Gwenda Hughes and Anthony Clarke, a major new writing policy was developed, making the Rep's studio theatre, renamed the Door, a regional centre for new plays equalled only by the Traverse in Edinburgh and the Royal Exchange in Manchester.

But it is also under both directorates that the responsibility to community engagement was taken on in full consciousness of Arts Council funding conditions. The result under Adams was the creation of the entirely new role of community animateur, and then the first Community Department which focused on an extensive programme of pre and post-performance workshops linked to community touring, a city-wide youth theatre consortium, a Studio programme devoted to 'Made in the West Midlands' local companies and the provision of stand-up comedy shows in local pubs. The legacy of Sir Barry Jackson took an unexpected turn when the abolition of the West Midlands County Council in 1986 released surplus money which was awarded to the Sir Barry Jackson Trust to finance an annual community touring project. Playwrights Anne Devlin, David Edgar and Stephen Bill were commissioned to write Heartlanders, a main stage, mass community play set in the Birmingham of 1989 which interweaved stories inspired by the city's migrant groups: Irish, Welsh, Polish, Caribbean and South Asian. Adams himself became a key figure in moves to expand opportunities for black actors, especially on the main stage, with bold and sometimes controversial colour-blind casting decisions. Under Alexander, there was a move towards more independent participatory creativity delivered by a small team of education associates and tutors working with a range of external institutions. In 2000, work with local schools on the main stage production of Shakespeare's Twelfth Night, for example, resulted in short devised performances presented as curtain raisers. The Christmas show the same year was Timberlake Wertenbaker's Cinderella the Ash Girl, and this was complemented by Cinderella Storybox, an exhibition created by pupils from 14 primary schools, who had worked with professional artists to create $3 \mathrm{D}$ visual landscapes inspired by the show. 
The reasons for the gloomy outcome of the simultaneous stabilisation, reappraisal and overhaul of the entire managerial policy are complex and beyond the scope of this essay AQ7 (see Cochrane 2003, 176-201), but suffice to say that failure was most apparent in poor

1 audience statistics even when the quality of the produced work was very high. The intense internal focus on maintaining the status of the Rep as a prominent producing theatre within the national theatre ecology, was not reflected in a commitment to the theatre from Birmingham's wider population, despite the efforts at community engagement.

\section{The practical adaptations of a beleagured city}

Thinking about the complex textures of the everyday city, Phil Hubbard points out that

everyday life in cities is after all, something that cannot be adequately prepared for: no matter how carefully scripted, urban life has a tendency to surprise, and we are constantly forced to improvise and adapt to events as they unfold around us.

Referencing the work of geographer Nigel Thrift, he emphasises that life in cities is characterised by

all manner of practical adaptation ... while individuals seldom have much control over what goes on in cities, they creatively improvise to open up 'pockets of interaction' in which they can assert and express themselves (no matter how fleetingly or inconsequentially). (Hubbard 2006, 95-96; also see Thrift 2003, 103)

The resignation of BCC leader, Albert Bore, in October 2015 signalled the limited ability of elected officials to control the local impacts of austerity. As a long-serving councillor for Ladywood, one of the poorer Birmingham wards, and council leader from 1999-2004 as well as Chair of the Economic Development Portfolio, Bore had been at the centre of economic and social regeneration of Birmingham through the 1980s and 1990s. Looking back over a 30-year career in 2013, he acknowledged that he and his colleagues had worked effectively with successive Conservative governments, including Margaret Thatcher's senior ministers. He had delivered, for example, one of the first major public-private partnerships through which European funding had been channelled (Hetherington 2013). On election to his second period of council leadership in 2012, Bore was faced with an implacable assault by central government on local authority resources, and he had inherited two colossal financial liabilities from the previous Conservative-Liberal Democratic-controlled council: the debt repayment on the Library itself - commissioned before the 2008 financial crash - and the approximately $£ 757$ million required following a Supreme Court ruling upholding a back-dated equal pay claim by 170 women council workers. Three years on the situation was worse. The Business Plan 2015+ stated that a total of $£ 821$ million would have to be found in savings. Most controversially, an independent review of the governance and organisational capabilities of BCC carried out by Sir Bob Kerslake, published in December 2014, identified fifteen key elements of city organisation that needed urgent change. Parts of Birmingham were amongst the most deprived in the country with many more poor children, low employment rates and inadequately skilled adults. Under successive administrations there had been a failure to address deeprooted problems which were often 'swept under the carpet'. Regeneration needed to 
go beyond the city centre to engage the whole city and its wider communities. But the most damning conclusions concerned children and young people. Several high-profile and avoidable deaths of vulnerable children led to an Ofsted condemnation of Children's Services as a 'national disgrace' (Kerslake 2014, 6-14). The so-called Trojan Horse crisis had exploded around an anonymous letter to Albert Bore in November 2013 detailing a strategy to run a number of Birmingham schools on potentially exclusionary and radicalising Islamic principles (Clarke 2014). One of Kerslake's criticisms a year later was that the creation of a civic leadership group representing credible independent voices recommended by the Trojan Horse Review Group had not yet happened. Viewed through the Kerslake report lens, the disparity between iconic civic aggrandisement and urban poverty and vulnerability encapsulates the worst effects of a flawed neoliberal ideology.

In this beleagured city what kind of practical adaptation is possible for the one regional producing theatre to open up 'pockets of interaction' with their community and ameliorate the pressures of precarity? How can the physical resources of building and people be deployed to best purpose? What kind of 'common sense' can prevail? Is it remotely possible to re-think neoliberalism within the terms of its original conception, as an ideology that sought to protect human dignity and individual freedoms within a framework of social protection, while warding off the charge of craven capitulation? Can a theatre building be a site for practising economic efficiency, civic responsibility and effective community engagement? Reviewing the most recent history of the REP, it becomes possible to tentatively argue that, whilst meeting the stringent economic requirements of austerity, the theatre has managed to achieve a number of its civic, artistic and social ambitions. Its engagement with, and embrace of, community-related policy and products, including work with children and young people, has been at the heart of its recent and relative economic success.

The REP is no longer recognisable as the model of autonomous producing theatre conceived by its founder in 1913. The one constant presence throughout its recent history has been Birmingham-born Executive Producer Stuart Rogers, who adopts the pragmatic position that on the whole audiences enjoy the product of theatre without taking much notice of its provenance. This neatly corresponded with the view of Bill Alexander's successor Jonathan Church who, abandoning the previous director's commitment to producing regionally distinctive theatre, considered that Birmingham audiences had been starved of the opportunity to see some of the successes of London theatre. Subsequent revivals of metropolitan successes were based on Church's sense that it is important to 'share tastes' with local people rather than attempt to impose them and he has also pursued a strategy of co-production, in common with other producing theatres. In the period since 2002, including the 2006-2010 tenure of the Rep's first woman Artistic Director, Rachel Kavanaugh, and three years of closure for interior restructuring and alignment to the Library, there has been no major deficit crisis. The first full financial year since reopening in 2014 saw a staggering 86 shows presented across three auditoria, the overwhelming majority of which were co-productions. The Company's annual report recorded revenue reserves of $£ 2,014,811$ - enough to keep the organisation operational for three months (Birmingham Repertory Theatre 2015).

What kinds of stories are being shared with Birmingham communities in this period of relative prosperity? The partnership with the Library has created a third shared space: a flexible 300-seater Studio. Programming in this space has recalled key moments in the 
producing history of the theatre. Frozen, Bryony Lavery's mesmerising three-actor play about child murder (premiered by Bill Alexander in 1998), was recreated for deaf audiences by The Fingersmiths, using British Sign Language as well as spoken English. In partnership with the Royal Court, Roxana Silbert directed the premiere of Gurpreet Kaur Bhatti's Khandan, a play about an extended British Asian family which brought Kaur Bhatti safely back to the REP for the first time since the Behzti furore in 2004 (Frost 2006) and attracted packed houses. The Studio's opening production, a jazz/hip-hop fusion of graphic video and choreography by Jonzi D saw the saxophonist Soweto Kinch performing a staged version of his album The Legend of Mike Smith. After years of effort, disappointment and resistance, the exclusion of black artists and audiences from the theatre is being meaningfully addressed. Partnership in the regional Eclipse Theatre consortium from 2003-2006 has established more confidence in the theatre's commitment to black theatre makers (Cochrane 2010, 132-135). Production sharing with the National Theatre and with West Yorkshire Playhouse brought Talawa Theatre Company in 2014 with Erroll John's Moon on a Rainbow Shawl and, in 2015, Talawa's all-black production of Arthur Miller's All My Sons. The predictably biggest popular success in 2014 featured locally born and nationally prominent comedian Lenny Henry in a boisterous stage version of the BBC Radio 4 comedy Rudy's Rare Records, set in Birmingham in a beleaguered Handsworth record shop and co-produced with the Hackney Empire.

Directly referencing the local has entailed a precarious balancing act between achieving community recognition and wider critical appraisal. In the centenary year, directed by Mike Bradwell in the Old Rep, local playwright Robin Nelson's relocation of Ibsen's Hedda Gabler to a leafy Birmingham suburb was given a cautious local welcome, but mauled by national critics. Roxana Silbert's outrageously farcical treatment of Moliere's Tartuffe again set in Birmingham and exploiting the age old rivalries between Brummies and Black Country 'yam yams', was thoroughly enjoyed by young audiences, including my own students, but gently disparaged nationally. In October 2015 in a co-production with the Theatre Royal, Stratford East, Silbert directed Tanika Gupta's adaptation of Meera Syal's semi-autobiographical coming of age novel set in a Staffordshire former mining village in the 1970s. The experience of first and second generation Indian-heritage migrants told with voices which blended South Asian with Black Country accents, evoked nostalgia and popular recognition across diverse groups of actors, community supernumeraries and audiences. As Silbert herself admitted, the piece was rather dramaturgically uneven, but it didn't deserve the sneering critique delivered by Quentin Letts in the Daily Mail who described it as a 'mushy sense of multiculturalism'. ${ }^{2}$

Bringing the community and community-oriented theatre products, with all their attendant multi-faceted 'mushiness' into the theatre, is a risky business which requires both nerve and ambition. The Brecht festival in the spring of 2014 was launched with Silbert's RSC production of Galileo featuring lan McDiarmid in the title role but was then transformed by playwright Mark Ravenhill as curator into an 'Epic Encounters' event which included comedy, cabaret, film, talks and interactive exhibitions that asked tough questions about hard times. In the same season, a major partnership of four regional theatres supported a touring Graeae Theatre Company production of The Threepenny Opera with a cast of differently abled actors. The homegrown production of The Mother directed by the REP's Associate Director Tessa Walker brought a complete cast of community actors onto the main stage working with Lorna Laidlaw as the mother and another locally grown 
professional actor Kyle Bell as her son Pavel. Here, the economical deployment of human resources came across as wholly in the radical spirit of the Brechtian lehrstüke. In April 2016, members of the REP's youth theatre were also directed on the main stage by Gwenda Hughes in an adaptation of Jonathan Coe's coming of age in 1970s' Birmingham novel The Rotter's Club.

\section{Youth and resilience}

I conclude where I began, with the REP's engagement with young people and what it might contribute to a culture of resilience within the theatre and its wider communities. Led since 2004 by Associate Director Steve Ball, learning and participation in a variety of forms across all generations are now central to the REP's policy, with a raft of programmes underpinned by local and national networks, trusts and alliances, all of which contribute to a carefully constructed, if undeniably fragile model of financial sustainability. ${ }^{3}$ The more directly theatre-related activities include the seasons of 'First Stages' plays for very young children presented in the Door and the now fifteen satellite youth theatres that weekly involve some 350 young people. The Neighbourhood REP project creates new work in partnership with community libraries across Birmingham. The 'Arts Champion' scheme initiated by BCC in 2004, which placed the city's leading arts organisations in each of Birmingham's ten constituencies to nurture arts engagement, placed the REP as champions for Erdington in the old industrial north east of the city. Local residents have been offered 30 minute plays for 'home' theatre and well as 'Hello Erdington' discounted tickets for main theatre productions. As the second largest city in the UK, Birmingham is also the most youthful city in Europe with over $45 \%$ aged under 30 . In 2004, Steve Ball launched a scheme to enable children born in two local inner city hospitals to have a special relationship with the theatre over a period of ten years. Two hundred and forty children were signed up to enjoy free theatre with those who maintained the relationship 'graduating' in 2014. The challenge of engaging with Birmingham's rapidly accelerating demographic complexity became evident in 2013, when a new generation was sought and the take-up was reduced to just 13 babies. ${ }^{4}$ The reason became clear when the Chief Midwife supplied the information that 52\% of the new mothers couldn't speak English at all and $48 \%$ had an average reading age of seven. The strategy adopted to salvage the scheme was to work with health visitors to distribute promotional material in Urdu, Polish and French - this last because of the growing Somali population. The take-up improved but the challenge to the way the theatre responds to population pressures within the city remains. Over the last three decades under successive governments, the powers formerly exercised by local education authorities over local schools in the mainstream educational system have been steadily eroded (Williams 2016). However, the resulting fragmentation has provided opportunities for independently funded REP education officers to work with schools. As these schools now have more control over their budgets, they are able to buy whole days/weeks/summer school packages of activity. Some of this has been funded through the Pupil Premium, launched by central government in 2014, which provides grants to both primary and secondary schools to help improve the attainment of individual physically and/or socially disadvantaged children. ${ }^{5}$ This has included work with non-mainstream schools such as the Mayfield Special School for children with special educational needs. Steve Ball himself has become a 
director of the CORE Educational Trust which oversees two of the former Trojan Horselinked schools (2016) and the REP's South Asian-heritage officer Bhavik Parmer works with children across the curricula in both schools, trying to inculcate values of tolerance, respect and inclusion against a background of continuing anxiety about Islamic radicalisation.

The name given to the REP Foundry programme which produced the work of Amahra Spence references of course the former industrial strength of the West Midlands which provided an economic base which ceased to be secure long ago. Just as the regional product has to be rethought in the context of city and region-wide precarity, so too I suggest has the 'product' of the 'producing' theatre. As both Stuart Rogers and Roxana Silbert make clear, the theatre's resilience is grounded in on the one hand flexibility and this means embracing money-making opportunities such as corporate training workshops, conferences and weddings as well as set-building contracts - and on the other being 'purposeful', as Silbert put it to me. This secure economic base means that the resources of the theatre can be opened up to sections of the community that the theatre has previously failed to reach, and as part of this they can 'reach in' young theatre makers in increasing numbers. The news of a $£ 750,000$ ACE grant in 2016 heralds the launch of a second industrially named initiative, FURNACE - a three year programme designed to produce large-scale projects which bring together international artists with 70 emerging young artists and over 3250 members of the local community (Birmingham Repertory Theatre 2016). And so the story goes on. As I was completing this article in July 2016, the REP had just hosted the annual artistic gathering of ASSITEJ (International Association of Theatre for Children and Young Audiences), which brought theatre companies from all over the world to Birmingham, carrying out school residencies 520 and performances targeting toddlers through to teenagers of different abilities and social backgrounds. ${ }^{6}$ The packed REP foyers signal a good year and an optimistic future. Beyond the REP, there is economic and political turmoil - locally, nationally and globally - threatening an even more unstable future. But I would like to hope that the triad of precarity, responsibility and resilience evidenced in the contemporary history of the REP may yet open up the pockets of interaction between communities across this beleaguered city.

\section{Notes}

1. Over time the way the theatre has been named has varied. At present, it trades as the REP. Previously Birmingham Rep or the Rep were more familiar names. Throughout this article I have adjusted the abbreviated name according to time period.

2. Personal interviews with Roxana Silbert and Stuart Rogers - 20 October 2015.

3. Information about youth and community activity provided in two personal interviews conducted with Steve Ball on 20 October 2015 and 19 January 2016.

4. In 2014 white British people made up 53.1\% of Birmingham's population, although this is itself a very diverse category. After this, the diversity is as follows: Pakistani heritage: $13.5 \%$; Indianheritage: $6.0 \%$; Black Caribbean: $4.4 \%$. There are growing numbers of migrants from African countries. By 2014, 238,313 Birmingham residents had been born outside the UK and $45 \%$ had arrived since 2004 (Birmingham City Council 2014).

5. For more information see 'Pupil Premium Funding and Accountability for Schools'. Accessed 3 August 2016. https://www.gov.uk/guidance/pupil-premium-information-for-schools-andalternative-provision-settings.

6. For more information go to www.ontheedge2016.com. Accessed 3 August 2016. 


\section{Disclosure statement}

AQ8 No potential conflict of interest was reported by the author.

\section{Notes on contributor}

Claire Cochrane is Professor of Theatre Studies at Worcester University. Her publications include Twentieth Century British Theatre Industry, Art and Empire (CUP, 2011) and Theatre History and Historiography Ethics, Evidence and Truth co-edited with Jo Robinson (Palgrave, 2016). She has published extensively on the Birmingham Repertory Theatre.

\section{References}

Anheier, Helmut K. 2005. Nonprofit Organisations: Theory, Management, Policy. London: Routledge.

Arts Council of Great Britain. 1984. The Glory of the Garden: The Development of the Arts in England - A Strategy for a Decade. London: Arts Council of Great Britain.

Birmingham City Council. 2014. "Population in Birmingham." Accessed 15 January 2016. http://www. birmingham.gov.uk/cs/Satellite?c=Page\&childpagename=Planning-and-Regeneration\% 2FPageLayout\&cid=1223096353755\&pagename=BCC\%2FCommon\%2FWrapper\%2FWrapper.

The Birmingham Repertory Theatre. 2015. Trustees' Report and Financial Statements for the year ended 31 March 2015.

Birmingham Repertory Theatre. 2016. "About Furnace." Accessed 10 September 2016. http://www. birmingham-rep.co.uk/files/downloads/5980/About+Furnace.

Brown, Graeme. "Sir Albert Bore: I Am Standing Down for the Good of Birmingham." Birmingham Mail, October 13, 2015. Accessed 30 October 2015. http://www.birminghammail.co.uk/news/midlandsnews/sir-albert-bore-am-standing-10254177.

Butler, Patrick. "'Local Government Cuts: The 'Jaws of Doom' Are Ready to Bite." Guardian, December 18, 2012. Accessed 30 October 2015. http://www.theguardian.com/society/2012/dec/18/localgovernment-cuts-jaws-doom-bite.

Clarke, Peter. 2014. Report into Allegations Concerning Birmingham Schools Arising from The 'Trojan Horse' Letter. London: Her Majesty's Stationary Office.

Cochrane, Claire. 2000. "Theatre and Urban Space: The Case of Birmingham Rep." New Theatre Quarterly 16 (2): 137-47.

570 Cochrane, Claire. 2001. Twentieth Century British Theatre Industry, Art and Empire, Cambridge: Cambridge University Press.

Cochrane, Claire. 2003. Birmingham Rep A City's Theatre 1962-2002, Birmingham: Sir Barry Jackson Trust.

CORE Education Trust. 2016. Accessed 9 September 2016. http://www.core-education.co.uk/.

Dorney, Kate, and Ros Merkin. 2010. The Glory of the Garden English Regional Theatre and the Arts Council 1984-2009. Newcastle upon Tyne: Cambridge Scholars.

Frost, Anthony. 2006. "Drama in the Age of the Kalyup: Behzti and Sikh Self-censorship." In Alternatives Within the Mainstream British Black and Asian Theatres, edited by Dimple Godiwala, 203-222. Newcastle: Cambridge Scholars Press.

Hartwich, Oliver Marc. 2009. "Neoliberalism: The Genesis of a Political Swearword." The Centre for Independent Studies Occasional Paper 114. London: Centre for Independent Studies.

Harvey, David. 2007. A Brief History of Neo-liberalism. Oxford: Oxford University Press.

Hetherington, Peter. "Sir Albert Bore, leader of Birmingham City Council, fights to prevent cuts." Guardian, April 23, 2013. Accessed 28 October 2015. http://www.theguardian.com/society/2013/ apr/23/albert-bore-birmngham-city-council.

Hubbard, Phil. 2006. City. London: Routledge.

Kerslake, Sir Bob. 2014. The Way Forward: An Independent Review of the Governance and Organisational Capabilities of Birmingham City Council. London: Queen's Printer and Controller of Her Majesty's Stationary Office. 
Little, Adrian. 2002. The Politics of Community Theory and Practice. Edinburgh: Edinburgh University Press.

Megson, Chris. 2012. Modern British Playwriting the 1970s Voices, Documents, New Interpretations. London: Methuen Drama.

Rawls, John. 1999. A Theory of Justice. Revised ed. Cambridge, MA: Belknap Press.

Silbert, Roxana, and Stuart Rogers. 2015. "Birmingham City Council Announces Funding Cuts - Here Is Our Response." Funding cuts eflyer, sent December 11, 2015. Accessed 11 December 2015. http://birminghamrepertorytheatre.cmail20.com/t/ViewEmail/y/1E93D02FDDEF34E1/4472D557A 7719E3B6CBD507C784BD83B.

Thrift, Nigel. 2003. "Space: The Fundamental Stuff of Geography." In Key Concepts in Geography, edited by Sarah L. Holloway, Stephen P. Rice, and Gill Valentine, 95-107. London: Sage.

Williams, James. 2016. "RIP, LEA: The Local Education Authority Vanishes." Accessed 8 September 2016. http://www.open.edu/openlearn/education/educational-technology-andpractice/educational-practice/rip-lea-the-local-education-authority-vanishes. 